\title{
STUDY ON LOCAL GOVERNMENT INVESTMENT PLANNING IN REGIONAL OWNED ENTERPRISES USING BSC AND SWOT ANALYSIS
}

\author{
Sjamsuridjal, Meily Surianti \\ Universitas Nasional Pasim, Bandung, Indonesia \\ irhsyamsurijal@gmail.com
}

\begin{abstract}
In an effort to increase regional economic growth and improve services to the community, the Regional Government of Cianjur Regency plans to increase local government investment in Perumdan Tirta Mukti Cianjur, a regional drinking water company owned by the Cianjur Regency Government. Related to the increase in capital participation, a study was conducted with the aim of i) Assessing the financial capacity of the Cianjur Regency Regional Budget on the planned allocation of funds for equity participation, ii) Analyzing the performance of Perumdan Tirta Mukti Cianjur on the plan to increase the capital participation of the Cianjur Regency Government in the $B U M D$, iii) Make recommendations for increasing regional equity participation. The study was conducted by analyzing regional financial capacity in the Regional Government Budget of Cianjur Regency, as well as conducting a BSC (Balance Score Card) analysis and SWOT (Strength Weakness Opportunity and Threat) analysis to assess the performance of BUMD (Perumdan Tirta Mukti Cianjur). To conduct the above study, a literature study, data collection and analysis have been carried out using the above method. From the results of the analysis it was concluded that i) Regional financial capacity which is presented in the Cianjur Regency Government Budget is still sufficiently free to carry out various development innovations, including for the addition of capital participation in the Tirta Mukti Housing, ii) The Performance of the Tirta Mukti Housing Perumdam is quite ready to add capital so that can improve drinking water services in Cianjur Regency. Based on this, it can be recommended to the Regional Government of Cianjur Regency to carry out regional capital participation in Perumdam Tirtamukti, in the framework of accelerating the fulfillment of service targets in the future. However, in the implementation of capital participation in these BUMDs, they must still follow the rules and provisions of the applicable laws and regulations, and carry out adequate supervision of the performance of these BUMDs.
\end{abstract}

Keywords: BSC; SWOT; BUMD performance; local government capital participation

* Corresponding author's e-mail: irhsyamsurijal@gmail.com 
EAJ (Economics and Accounting Journal) - Vol. 3, No. 1, Jan 2020 - Sjamsuridjal, Surianti

\section{INTRODUCTION}

In an effort to increase regional economic growth and improve services to the community, the Cianjur District Government plans to increase local government investment in Perumdan Tirta Mukti Cianjur, a regional drinking water company owned by the Cianjur District Government. Related to this increase in equity participation, there are a number of issues that need to be answered, including:

1) Can the Cianjur District Government Budget (APBD) be sufficient to provide investment in Perumdan Tirta Mukti?

2) Is it appropriate for Perumdam Tirta Mukti to be given additional investment by the Cianjur District Government?

3) What kind of recommendations should be given regarding the investment plan of the Cianjur District Government in Perumdam Tirta Mukti?

Based on the existing problems, a study was conducted with the aim of:

1) Assess the financial capacity of the Cianjur District Government Budget on the planned allocation of funds for equity participation

2) Analyzing the performance of Public Corporation and Tirta Mukti Cianjur on the plan to increase equity participation Cianjur District Government in BUMD.

3) Making recommendations for increasing regional capital participation.

\section{LITERATURE REVIEW}

\subsection{Study of Regional Financial Capacity}

Law number 23 of 2014 concerning Regional Government, states that Regions can make capital participation in State-Owned Enterprises (BUMN) and / or Regionally-Owned Enterprises (BUMD). In the event that the APBD is estimated to be a surplus, the APBD can be used for Regional financing expenditures stipulated in the local regu;ation (Perda) on APBD. One of the expenditure can be used to finance the participation of regional capital.

Other provisions, namely Government Regulation No. 27 of 2014 concerning Management of State-Owned Property (BMN) / Regional-Owned Property (BMD), stipulates that the Capital Participation of the Central / Regional Government can be carried out with consideration of:

a. State-Owned Property (BMN) / Regional-Owned Property (BMD) which from the beginning of its procurement in accordance with budgeting documents is intended for BUMN / BUMD or other legal entities that are owned by the state in the context of government assignment; or

b. BMN / BMD is more optimal if it is managed by BUMN / BUMD or other state-owned legal entities, both existing and to be formed.

The participation of the Central / Regional Government Capital on BMN in the form of land and / or buildings in the Property User is carried out by the Property User after 
EAJ (Economics and Accounting Journal) - Vol. 3, No. 1, Jan 2020 - Sjamsuridjal, Surianti

obtaining approval from the Property Manager.

Central / Regional Government Capital Participation in BMN / BMD other than land and / or buildings carried out by:

a. Property Manager, for BMN; or

b. Property Manager after obtaining approval from the Governor / Regent / Mayor, for BMD.

According to Government Regulation No. 27 of 2014 concerning Management of State / Regional Government Property, Participation of Central / Regional Government Capital is the transfer of ownership of State / Regional Government Property which was originally assets that are not separated into assets that are separated for calculation as capital / shares of the state or region in stateowned enterprises, regionallyowned business entities, or other legal entities owned by the state.

Participation of Central / Regional Government Capital on State / Regional Property is carried out by:

a. Property User after obtaining approval from the Property Manager, for State Property; or

b. Property Manager after obtaining approval from the Governor / Regent / Mayor, for Regional Owned Property.

Participation of Central / Regional

Government Capital on State /

Regional Property is carried out by:

a. Property Manager, for State Property which is in the Property Manager;

b. Property User after obtaining approval from the Property Manager, for State Property which is in the Property User; or c. Property Manager after obtaining approval from the Governor / Regent / Mayor, for Regional Owned Property.

Article 14 of the Minister of Domestic Affairs Regulation No. 52 of 2012 concerning Guidelines for the Management of Regional Government Investment, states that the participation of regional capital can be done if the regional budget is estimated to be surplus. In this case the surplus means the amount of regional income exceeds regional expenditure. Usually in budgeting the budget between revenue and expenditure is always planned to be balanced, but after the budget is realized there is always more budget, due to various reasons such as savings in spending, and / or activities / spending that cannot be carried out so that later on the realization after calculation by Government Auditor (BPK) becomes available the rest is more or may be called a surplus. Therefore, usually the regional capital investment expenditure is carried out in financing by looking at the previous year's SILPA (remaining budget).

In regional expenditures there are mandatory and optional expenditures. Expenditures which are mandatory such as personnel expenditure and spending to fulfill basic community services must be budgeted in the APBD. Other expenditures follow the regional development plans that have been determined including local government investment in the BUMD, the realization of which depends on regional financial capacity. If the ability of the region is classified as moderate or high, 
EAJ (Economics and Accounting Journal) - Vol. 3, No. 1, Jan 2020 - Sjamsuridjal, Surianti

then the region can freely innovate through various development programs, including making capital participation in its BUMD. But on the contrary if the regional financial capacity is classified as low, it is rather difficult to meet all planned expenditures.

\subsection{Balance Scorecard and SWOT Analysis}

\section{Balance Scorecard}

Regional companies or regionally-owned enterprises (BUMD) are established by regional governments as profit centers. This means that the Regional Enterprise is an organizational unit within the Regional Government established to generate revenue for the regional government that established it. Thus, in addition to being required to prepare financial reports, the regional government of a province / district / city is also the user of the financial statements of another entity, namely a regional company or BUMD in its environment.

This will be seen from the aspect of agency theory (agency theory). Jensen and Meckling (1976) in Masdupi (2005, 59) define agency theory as the relationship between agents (management of a business) and principals (business owners). In this connection, the principal (the people / DPRD) entrusts the processing to the agent (local government). In the context of the theory, local governments act as agents or as principals. As an agent, the regional government is tasked with managing the principal funds, namely the people represented by the DPRD. Conversely, for principals, local governments hand over wealth management to regional companies or BUMDs that act as agents. In its position as a principal, local governments must be able to analyze the financial statements produced by their agents, namely regional companies.

As a profit-oriented company, regionally-owned enterprises (BUMD) must be able to manage their organizations as efficiently as possible, so that they are able to achieve organizational goals. To be able to manage organization efficiently, then management of BUMD requires tools / tools that can be used to assess and evaluate company performance. The results of the assessment and evaluation can later be used as a basis for determining the company's strategy in achieving its goals.

One of the tools / performance appraisal tools that is currently considered sufficient to represent the needs of company management to be able to appraise performance appropriately is the Balanced Scorecard (BSC), which in management accounting is known as an analytical tool that aims to support the management process. The Balance Scorecard was developed by Norton in 1990, providing a comprehensive framework for elaborating missions into strategic goals. Comprehensive strategic goals can be formulated because the Balanced Scorecard uses four perspectives, namely finance, customers, internal business processes, and learning and growth. The financial perspective provides financial goals that need to be achieved by the organization in 
EAJ (Economics and Accounting Journal) - Vol. 3, No. 1, Jan 2020 - Sjamsuridjal, Surianti

realizing its vision. The customer perspective provides an overview of the intended market segments and customers along with the demands of the needs served by the organization in an effort to achieve certain financial goals. The internal business process perspective provides an overview of the processes that must be built to serve customers and to achieve certain financial goals. The learning and growth perspective is a trigger for building personnel competition, information systems infrastructure, and the work environment necessary to realize financial goals, customers, and internal business processes.

\section{Financial perspective}

Financial performance measures indicate what strategy and its implementation is able to contribute in generating profits for the company (Munawir, 2011). To make the organization of an institution that is able to be creative, it requires excellence in finance. Through excellence in this field, organizations master the resources that are needed to realize three other strategic perspectives namely customer perspective, internal business process perspective, and learning and growth process perspective. In a financial perspective, performance to measure whether a company's strategy, implementation and implementation will bring improvement to the company.

Financial perspective consists of financial ratios contained in financial statements, namely:

\section{1) Revenue Growth Ratio (RPP).} This ratio is used to measure and find out the extent of growth and income in the company.

$\mathbf{R P P}=($ Current year's revenueLast year's revenue) / (Last year's revenue) x $100 \%$

2) Cost Growt Ratio (RPB). This ratio is used to determine and measure changes in costs incurred and incurred by the company.

RPB = (Current year's costs Last year's costs) / (Last year's costs) x $100 \%$

3) ROA (Return On Assets). This ratio is used to measure the level of net income obtained by the company from total assets.

ROA $=($ Net Income $) /$ (Average Total Assets) x 100\%

4) ROE (Return On Equity). This ratio is used to measure the level of net income obtained by the company on the invested capital. $\mathrm{ROE}=$ (Net profit) / (Own capital) x $100 \%$

\section{5) Leverage Ratio}

This ratio is used to measure the amount of company assets financed by debt or capital from creditors.

Leverage $=($ Total Debt $) /($ Total Assets) x 100\%

\section{Customer perspective.}

For customers, the company identifies and defines customers and their market segments. The company is expected to be able to make a market segmentation and determine the target market that is most likely to be targeted according to the ability of resources and the company's longterm plan. This perspective has several key measurements of successful outcomes with good formulation and application of 
EAJ (Economics and Accounting Journal) - Vol. 3, No. 1, Jan 2020 - Sjamsuridjal, Surianti

strategies. Strategic objectives from a customer perspective are firm equity including increasing customer trust in the products and services offered by the company, the speed of service provided, and the quality of the company's relationship with its customers.

Performance measurement at the customer's perspective uses indicators:

\section{1) Customer Satisfaction}

2) Customer Retention

Customer retention $=($ Number of customers last year - Number of customers current year) / (Number of customers last year) $\mathrm{x} 100 \% \mathrm{x}$ $100 \%$

3) Customer Acquisition

Percentage of acquisition = (Number of customers current last year - Number of customers last year) / (Number of customers last year) x $100 \%$

$\begin{array}{llr}\text { Internal business } & \text { process } \\ \begin{array}{c}\text { perspective } \\ \text { Managers }\end{array} & \text { must focus their }\end{array}$ attention on internal business processes that determine customer satisfaction on company performance from a customer perspective. The performance from this perspective is obtained from the internal business performance process held by the company. Companies must choose the processes and competencies that are superior and determine the measures to assess the performance of the processes and competencies. The strategic objectives of this business process are organizational capital, such as improving the quality of service processes to customers, computerizing service processes to customers, and implementing technology infrastructure that facilitates service to customers. The Balanced Scorecard approach divides measurements in the perspective of internal business processes into three parts, namely: (1) Innovation, (2) Operations, and (3) After sales service.

\section{Learning and growth perspective}

\section{People}

Workers at companies today are further required to be able to think critically and evaluate processes and the environment to be able to propose improvements. Therefore, in measuring the company's strategy, one of them must be specifically related to the ability of employees, namely whether the company has planned an increase in the ability of its human resources. In relation to human resources, there are three things that need to be reviewed in implementing the Balanced Scorecard:

1. The level of employee satisfaction.

Employee satisfaction is a condition for increasing productivity, quality, service to consumers and speed of reacting. Employee satisfaction is important, especially for service companies.

2. Employee retention

Employee retention is the company's ability to retain its best workers to remain in the organization. Companies that have invested in human resources will be in vain if they do not keep their employees in the company.

3. Employee productivity 
EAJ (Economics and Accounting Journal) - Vol. 3, No. 1, Jan 2020 - Sjamsuridjal, Surianti

Employee Productivity is the result of the average effect of increasing expertise and the spirit of innovation, improvement of internal processes, and the level of customer satisfaction. The aim is to link the outputs made by employees to the total number of employees. Employee productivity is used to determine employee productivity in working for a certain period. The measurement is by comparing the operating profit with the number of employees.

\section{System}

Employee motivation and skills alone are not enough to support the achievement of learning and growth goals if they do not have sufficient information. Employees in the operational field need fast, timely and accurate information as feedback, therefore employees need an information system that has adequate quality and quantity to meet those needs.

\section{Organizational Procedure}

Procedures carried out by an organization need to be considered to achieve a reliable performance. Procedures and routine improvements must be continued because perfect employees with abundant information will not contribute to business success if they are not motivated to act in harmony with company goals.

In this perspective the measurement components used are:

1. Employee Productivity = (Operating Profit) / (Number of employees)
2. Employee retention $=($ Number of employees leaving) / (Total current year employees) x 100\%

\section{SWOT Analysis (Strengths,} Weaknesses, Opportunities, and Threats)

SWOT analysis is a strategic planning method used to evaluate strengths, weaknesses, opportunities and threats in a project or business speculation. This process involves setting specific goals from business or project speculation and identifying internal and external factors that support and which do not achieve these goals.

SWOT analysis can be applied by analyzing and sorting out various things that affect the four factors, then applying it in the SWOT matrix image, where the application is how strengths are able to take advantage of the opportunities available, how to overcome weaknesses (weaknesses) that prevent the advantages (opportunities) of the opportunities (opportunities) that exist, then how strengths are able to deal with threats (threats) that exist, and finally is how to overcome weaknesses that can make threats become real or create a new threat.

\section{RESEARCH METHOD}

The research method was conducted using descriptive methods and analysis of secondary data. To get confidence in the increase in investment that will be budgeted by the Regional Government of Cianjur in BUMD, this study will examine several aspects of investment in local government in the form of: 
EAJ (Economics and Accounting Journal) - Vol. 3, No. 1, Jan 2020 - Sjamsuridjal, Surianti

\section{Analysis of Regional Financial Capabilities}

The investment that will be planned by the Regional Government of Cianjur Regency must also look at the regional financial capacity (KKD) owned by the Regional Government of Cianjur Regency. The study will be conducted on the Cianjur Regency APBD along with related matters, to see whether the Cianjur Regency APBD has the ability to add capital to the BUMD or not.

\section{Performance Analysis of Perumdam Tirta Mukti.}

Conduct a performance analysis of Perumdam Tirta Mukti, so that the planned capital increase in the BUMD can be accounted for. The calculation of benefits and costs must also include an analysis of social costs and benefits arising from LG investment that will be carried out by the public sector BUMD. Costs and benefits often cannot be directly measured in units of money. The step of calculating the benefits and investment costs in units of rupiah sometimes there are difficulties so that the benefit cost analysis techniques are very suitable to be applied. Choose investments that have the greatest benefits and high cost effectiveness. Within this scope will also be examined about the business feasibility of the BUMD to be disbursed funds.

\section{Conclusions}

In an effort to give confidence to the Regional Government of Cianjur Regency over the planned improvement capital participation that will be carried out at BUMD, the study will provide conclusions of study results that can be academically accountable, as well as provide recommendations to the Regional Government of Cianjur on plans to increase capital participation in the Tirta Mukti Cianjur Public Housing, so that it is expected to be a guideline and reference in accelerating the implementation of development regional investment for Cianjur Regency Government.

\section{RESULTS AND DISCUSSION}

After the required data is obtained, an analysis is carried out. Data obtained from the Regional Secretariat of Cianjur Regency which is secondary data, namely in the form of a summary of the 2017 Fiscal Year Regional Budget, Company Profile Perumdam Tirta Mukti, Perumdam Tirta Mukti Company Profile Summary, and Perumdam Profit Loss report. The data can be summarized in the following table.

Table 1: Profile Overwiev of Perumdam Tirta Mukti Cianjur

\begin{tabular}{|c|c|c|c|c|}
\hline No & Description & 2013 & 2014 & 2015 \\
\hline 1 & Employee & 329 & 370 & 439 \\
\hline 2 & Cpital & 51.666 .967 .049 & 71.931 .835 .009 & 86.931 .835 .009 \\
\hline 3 & Asset & 48.536 .788 .195 & 68.550 .001 .965 & 82.678 .971 .583 \\
\hline 4 & Obligation & 8.323.584.719 & 7.270 .941 .288 & 6.254.229.266 \\
\hline 5 & Equity & 40.213 .203 .475 & 61.279 .060 .677 & 76.424 .742 .327 \\
\hline
\end{tabular}


EAJ (Economics and Accounting Journal) - Vol. 3, No. 1, Jan 2020 - Sjamsuridjal, Surianti

\begin{tabular}{|c|c|c|c|c|}
\hline 6 & Income & 33.729 .879 .018 & 39.966 .472 .840 & 44.299 .041 .882 \\
\hline 7 & Cost & 33.521.291.231 & 36.839.294.591 & 44.153.360.232 \\
\hline 8 & Profit & 208.587 .787 & 127.178 .249 & 145.681 .650 \\
\hline 9 & Government Share & 13.300 .000 .000 & 25.187 .911 .000 & 15.000 .000 .000 \\
\hline 10 & Auditor & $\begin{array}{l}\text { Abubakar Usman \& } \\
\text { Rekan }\end{array}$ & Risman \& Aripin & $\begin{array}{l}\text { A Rachman \& } \\
\text { Soetjipto WS }\end{array}$ \\
\hline 11 & Opinion & WTP & WTP & WTP \\
\hline 12 & Ownership & \multicolumn{3}{|c|}{$100 \%$ owned by Cianjur District Government } \\
\hline
\end{tabular}

Table 2. Employee Composition Based on Education Level per July 2015

\begin{tabular}{|llll|}
\hline Educational Level & Number of Employee & Percentage \\
\hline- & Master & 13 & $2,96 \%$ \\
- & Bachelor & 155 & $35,31 \%$ \\
- & Diploma & 11 & $2,50 \%$ \\
- & SLTA & 227 & $51,71 \%$ \\
- & SLTP & 19 & $4,33 \%$ \\
- & SD & 14 & $3,19 \%$ \\
Amount & 439 & $100,00 \%$ \\
\hline
\end{tabular}

Source: Staffing Data of Perumdam Tirta Mukti, per December 2015

\subsection{Analysis of Regional Financial Capabilities}

From this amount of data an analysis was carried out using the above theoretical approach. Globally the analysis is divided into two parts, namely an analysis of the financial capabilities of the Cianjur Regency Government and an analysis of the performance of BUMDs.

According to Sjamsuridjal and Abin Suarsa (2018), the plan to increase the capital participation of the Cianjur Regency Government in Perumdam Tirta Mukti Cianjur, which is owned by the Cianjur Regency Government every year for five years starting in the 2017 fiscal year, can be considered because the regional financial capacity is sufficient to do so, and is part of an effort to increase local revenue in the coming years. When viewed in terms of regional financial capacity, the value of additional equity participation for the three BUMDs compared to KKD which reached
853.1 billion, the percentage is still very small, estimated to still be below 3\%. This means that in terms of regional financial capacity it is still possible to carry out such capital investments.

\section{Analysis of Perumdam Tirta Mukti Cianjur's Performance}

For measurement of financial performance, the measures used are Revenue Growth Ratio (RPP), Cost Growth Ratio (RPB), Return on Assets (ROA), Return on Equity (ROE), and Leverage Ratio. Following are the data used to calculate the ratios of financial performance in question:

When viewed in terms of regional financial capacity, the value of additional equity participation for the three BUMDs compared to KKD which reached 853.1 billion, the percentage is still very small, estimated to still be below 3\%. This means that in terms of regional 
EAJ (Economics and Accounting Journal) - Vol. 3, No. 1, Jan 2020 - Sjamsuridjal, Surianti

financial capacity it is still possible to carry out such capital investments.

\section{Analysis of Perumdam Tirta Mukti Cianjur's Performance}

For measurement of financial performance, the measures used are Revenue Growth Ratio (RPP), Cost
Growth Ratio (RPB), Return on Assets (ROA), Return on Equity (ROE), and Leverage Ratio. Following are the data used to calculate the ratios of financial performance in question:

Table 3: Net Cost \& Revenue Periode 2011-2015

\begin{tabular}{|l|c|c|c|c|c|}
\hline & $\mathbf{2 0 1 1}$ & $\mathbf{2 0 1 2}$ & $\mathbf{2 0 1 3}$ & $\mathbf{2 0 1 4}$ & $\mathbf{2 0 1 5}$ \\
\hline Pendapatan & $25,072,873,421$ & $28,943,034,682$ & $33,729,879,018$ & $36,966,472,840$ & $44,299,041,882$ \\
\hline Biaya & $28,039,493,824$ & $28,772,058,974$ & $33,521,291,231$ & $36,839,294,591$ & $44,153,360,232$ \\
\hline
\end{tabular}

Tabel 4: Net Profit, Aktiva, Own Capital, and Debt 2011-2015

\begin{tabular}{|l|c|r|r|r|r|}
\hline & $\mathbf{2 0 1 1}$ & $\mathbf{2 0 1 2}$ & \multicolumn{1}{|c|}{$\mathbf{2 0 1 3}$} & \multicolumn{1}{c|}{$\mathbf{2 0 1 4}$} & \multicolumn{1}{c|}{$\mathbf{2 0 1 5}$} \\
\hline Laba bersih & $(2,966,620,403)$ & $170,975,708$ & $208,587,787$ & $127,178,249$ & $145,681,650$ \\
\hline Total Aktiva & $28,928,324,794$ & $35,664,630,963$ & $48,536,788,195$ & $68,550,001,965$ & $82,678,971,583$ \\
\hline Modal Sendiri & $20,033,639,980$ & $26,704,615,689$ & $40,213,203,475$ & $61,279,060,677$ & $76,424,742,327$ \\
\hline Total Hutang & $8,894,684,816$ & $8,960,015,274$ & $8,323,584,719$ & $7,270,941,288$ & $6,254,229,266$ \\
\hline Rata2 TA & & $32,296,477,879$ & $42,100,709,579$ & $58,543,395,080$ & $75,614,486,774$ \\
\hline
\end{tabular}

Table 5: Ratio of Revenue and Cost Growth

\begin{tabular}{|c|c|c|c|c|}
\hline & 2012 & 2013 & 2014 & 2015 \\
\hline RPP & 0.154 & 0.165 & 0.096 & 0.198 \\
\hline $\mathrm{RPB}$ & 0.026 & 0.165 & 0.099 & 0.199 \\
\hline
\end{tabular}

From the table above it can be seen that revenue growth from 2012 to 2015 is not significant. Even in 2014 it experienced a slight decline, although it finally rose again in 2015 . When compared to revenue growth with the cost growth that occurred in 2012, 2014 and 2015, it was seen that the ratio of cost growth was greater - although the difference was very small - than the ratio of income growth. This indicates that the company still has to improve efficiency in carrying out its operational activities.
Table 6: Ratio of ROA, ROE, and Leverage

\begin{tabular}{|l|l|l|l|l|}
\hline & $\mathbf{2 0 1 2}$ & $\mathbf{2 0 1 3}$ & $\mathbf{2 0 1 4}$ & $\mathbf{2 0 1 5}$ \\
\hline ROA & 0.0053 & 0.0050 & 0.0022 & 0.0019 \\
\hline ROE & 0.0064 & 0.0052 & 0.0021 & 0.0019 \\
\hline Leverage & 0.2512 & 0.1715 & 0.1061 & 0.0756 \\
\hline
\end{tabular}

From the table above it can be seen that the ratio of return on assets is very small, and even tends to decrease from year to year. Likewise, the ratio of return on equity, its value is very small and also has decreased from year to year. This shows that the company is not optimally managing its assets in order to generate profits. The decreasing ROA shows that the company's efficiency actually decreased from 2012 to 2015 . The decreasing ROE indicates that the addition of own capital has also not been able to 
EAJ (Economics and Accounting Journal) - Vol. 3, No. 1, Jan 2020 - Sjamsuridjal, Surianti

increase the company's ability to generate profits.

In general, it can be said that the company's financial performance has not shown encouraging results. Efforts are still very much needed from the company's management in order to improve its performance in the future.

\section{Customer perspective}

Performance assessment from a customer's perspective is measured using three indicators, namely customer satisfaction, customer retention, and customer acquisition. Assessment of customer satisfaction indicators can be done by survey methods, i.e. ask the company's customers directly their perceptions about the company's services. For indicators customer retention and customer acquisition can be calculated using data on the number of existing customers. The following are data and calculation results for each indicator:

Table 7: Number of Customers 2012 $-2016$

\begin{tabular}{|c|c|c|c|c|}
\hline $\mathbf{2 0 1 2}$ & $\mathbf{2 0 1 3}$ & $\mathbf{2 0 1 4}$ & $\mathbf{2 0 1 5}$ & $\mathbf{2 0 1 6}$ \\
\hline 32,692 & 34,322 & 37,608 & 41,027 & 48,391 \\
\hline
\end{tabular}

Table 8: Ratio of Customer Retention and Acquisition 2012 - 2016

\begin{tabular}{|l|r|r|r|r|}
\hline & \multicolumn{1}{|c|}{2013} & \multicolumn{1}{c}{2014} & \multicolumn{1}{c|}{2015} & \multicolumn{1}{c|}{2016} \\
\hline Customer Retention & $(0.05)$ & $(0.10)$ & $(0.09)$ & $(0.18)$ \\
\hline Acqutition Percentage & 0.05 & 0.10 & 0.09 & 0.18 \\
\hline
\end{tabular}

This perspective requires company management to pay serious attention to three components in the company, namely people, systems, and organizational procedures. In this perspective the measurement components used are:
Viewed from the two tables above, the increase in the number of customers from year to year is quite encouraging. There are three possible causes of this condition. The first possibility is the company's ability to provide satisfying services to customers. The second possibility is that market share is still very wide open, and there are still no significant competitors. While the third possibility is the occurrence of the first and second possibilities simultaneously. The most dominant possibility can be answered if the company conducts a customer satisfaction survey.

\section{Internal business process}

The Balanced Scorecard approach divides measurements in the perspective of internal business processes into three parts, namely: (1) Innovation, (2) Operations, and (3) After sales service. These three indicators cannot be used to measure the performance of the Tirta Mukti PDAM in Cianjur Regency. The measurement cannot be done because the available data is not enough. Going forward, it is recommended that company management begin to implement internal business process measurements, as an effort to improve company performance.

\section{Learning and growth}

Employee Productivity $=($ Operating Profit) / (Number of employees)

Employees' retensation $=($ Number of outgoing employees) / (Total current year employees) x $100 \%$

The performance appraisal of these two indicators cannot be used 
EAJ (Economics and Accounting Journal) - Vol. 3, No. 1, Jan 2020 - Sjamsuridjal, Surianti

to measure the performance of PDAM Tirta Mukti, Cianjur Regency. The measurement cannot be done because the available data is not enough. In the future, it is recommended that company management begin to apply measurement aspects of learning and growth as an effort to improve company performance.

\subsection{SWOT analysis}

SWOT analysis is done by identifying the strengths and weaknesses of the company, as well as identifying opportunities and challenges faced by the company. The results of the SWOT analysis can be used to consider various possible strategies for the company, to be able to improve its performance maximally.

The following is a SWOT analysis from PDAM Tirta Mukti Cianjur Regency:

\section{Strengths}

a. Has experience as a Regional Water Company for approximately 42 years.

b. The number of PERUMDAM Cianjur Regency staffs as of December 2015 was 439 employees, with an education level of $2.96 \%$ Postgraduate, $35.31 \%$ Undergraduate, $2.5 \%$ Undergraduate, $51.71 \%, 4.33 \%$ Junior High School, and 3.19\% Elementary School.

c. Improved financial performance, where in 2010-2012 the company still suffered losses, but since 2013-2015 the company has posted profits.

d. An increase in the number of customers by $9 \%$ in 2015 , where in 2014 the number of subscribers was 37,608 , while in 2015 it was 41,027, and is expected to continue to increase.

e. Increased\% of water sales from production and $\%$ of water sales from distribution in 2014 were $63.10 \%$ and $70.90 \%$ and in 2015 were $64.98 \%$ and $72.00 \%$, and are expected to continue to increase.

\section{Weaknesses}

a. Management capability that is still lacking in managing company assets to obtain optimal profit, indicated by a very small ROA and ROE ratio.

b. Unstable profit growth, with numbers going up and down.

c. Management does not yet have a comprehensive strategic plan in order to improve company performance.

d. Efficiency in managing company activities is not optimal.

\section{Opportunities}

a. The development of the population of Cianjur Regency from 2014 to 2021 is projected to experience an average growth of $1.715 \%$ per year.

b. In Cianjur District there are 32 subdistricts where only 10 subdistricts are included in the PERUMDAM service area of Cianjur Regency.

c. The capacity of water sources in Cianjur Regency of 2396 (1 / sec) was only utilized in 2014 and 2015, respectively 473 (1 / $\mathrm{sec})$ or $19 \%$ and $503(1 / \mathrm{sec})$ or $20 \%$. 
EAJ (Economics and Accounting Journal) - Vol. 3, No. 1, Jan 2020 - Sjamsuridjal, Surianti

d. The percentage of households by source of drinking water, only $3.19 \%$ of households that source their drinking from metered tap water and $0.09 \%$ from retail piped water.

e. Regency Government that continues to be committed to helping companies improve performance and achieve the company's vision and mission.

\section{Threats}

a. The possibility of new competitors

b. Changes in the composition of district government policy makers that can cause changes in commitment to the company

\subsection{Analysis of the Potential for Future Enterprise Development}

\section{Analysis based on financial} performance

\section{Although financial} performance has not shown too encouraging results, the potential of the company is still very large in improving its performance. Having previously always posted a loss, and finally starting from 2012 until 2015 data continued to record profits, showing management's commitment to improve its performance.

Following are the projected data made by management in its business plan until 2021 if the district government adds capital investment for the next 5 years. It will be seen that the potential for future company development is still very wide open.

Table 10. Projections of Water Production and Distribution of Sold Water

\begin{tabular}{|c|c|c|c|c|}
\hline NO & TAHUN & PRODUKSI & DISTRIBUSI & TERJUAL \\
\hline 1 & 2014 & 10.273 .542 & 9.143 .453 & $6.482 .308,00$ \\
2 & 2015 & 10.944 .020 & 9.876 .978 & $7.111 .424,00$ \\
3 & 2016 & 14.810 .875 & 13.391 .597 & $9.687 .782,33$ \\
4 & 2017 & 16.417 .331 & 14.914 .404 & $10.856 .442,62$ \\
5 & 2018 & 17.701 .649 & 16.157 .287 & $11.827 .716,78$ \\
6 & 2019 & 18.960 .879 & 17.413 .800 & $12.823 .163,01$ \\
7 & 2020 & 20.212 .605 & 18.670 .822 & $13.811 .319,53$ \\
8 & 2021 & 21.528 .553 & 20.000 .707 & $14.840 .524,29$ \\
\hline
\end{tabular}

Table 11. Percentage of Sales of Water Produced and Distributed

\begin{tabular}{|c|c|c|c|}
\hline NO & TAHUN & $\begin{array}{c}\text { \% PENJUALAN AIR } \\
\text { DARI PRODUKSI }\end{array}$ & $\begin{array}{c}\text { \% PENJUALAN AIR } \\
\text { DARI DISTRIBUSI }\end{array}$ \\
\hline 1 & 2014 & 63,10 & 70,90 \\
2 & 2015 & 64,98 & 72,00 \\
3 & 2016 & 65,41 & 72,34 \\
4 & 2017 & 66,13 & 72,79 \\
5 & 2018 & 66,82 & 73,20 \\
6 & 2019 & 67,63 & 73,64 \\
7 & 2020 & 68,33 & 73,97 \\
8 & 2021 & 68,93 & 74,20 \\
\hline
\end{tabular}

\section{The Results of the SWOT Analysis}

From the results of the SWOT analysis it can be seen that the combination of strengths and opportunities owned by the company provides excellent potential for companies to develop themselves in the future. The strength of the company is already strong enough as 'capital' in achieving the company's vision and mission. The combination of strengths and opportunities will enable the company to overcome the company's weaknesses and to overcome existing threats.

The addition of working capital every year for the next five years by the Regency Government will increase the flexibility for company management to increase human resource capacity and improve 
EAJ (Economics and Accounting Journal) - Vol. 3, No. 1, Jan 2020 - Sjamsuridjal, Surianti

company infrastructure, so that management can provide better services to customers, improve efficiency in carrying out operational activities, and will ultimately improve overall company performance, not only financial performance but also performance from a non-financial perspective.

\section{Analysis of Benefits to be Received by the Community}

The addition of working capital of PDAM Tirta Mukti Cianjur Regency by the Cianjur Regency Government will increase the company's ability to carry out its operational activities, so that the people of Cianjur Regency will receive various benefits from the company. Some of the most important benefits are: (a) meeting basic water needs for the community and increasing numbers of people served by clean water, (b) free installation of new water connections, and (c) the community can utilize the new water source by means of a clean water treatment system .

With the three benefits above, the people of Cianjur Regency will improve the quality of their health, and improving the quality of health will improve the quality of life. Improving the quality of life will in turn increase the level of welfare and the happiness index of life of the people of Cianjur Regency.

\section{CONCLUSION}

Based on a number of analyzes of regional financial capacity above, it can be concluded that the Cianjur Regency Government has good financial capacity, which can be used by the Cianjur Regency Government to carry out development planning in various fields as freely as planned. However, the Regional Government of Cianjur Regency still has to make various efforts to increase its original regional income so that dependence on the Central Government can be reduced. Both of these can be mutually supportive, namely a good regional financial capability, part of which can be used to make various efforts to increase local revenue, ranging from intensification \& extensification of regional taxes and levies, to development activities that can stimulate an increase in the regional economy, including increased local government investment in BUMD owned by Cianjur Regency Government.

From the results of the SWOT analysis it can be seen that the combination of strengths and opportunities owned by the company provides excellent potential for companies to develop themselves in the future. The strength of the company is already strong enough as 'capital' in achieving the company's vision and mission. The combination of strengths and opportunities will enable the company to overcome the company's weaknesses and to overcome existing threats.

The addition of working capital every year for the next five years will increase the flexibility for company management to increase the capacity of human resources and improve company infrastructure, so that management can provide better services to customers, improve efficiency in carrying out operational activities, and ultimately will 
EAJ (Economics and Accounting Journal) - Vol. 3, No. 1, Jan 2020 - Sjamsuridjal, Surianti

improve overall company performance, not only financial performance but also performance from a non-financial perspective.

Based on the results of an analysis of financial performance at Perumdan Tirta Mukti, it can be concluded that Perumdam Tirta Mukti is a company that is ready to accept additional equity participation in order to improve performance and

\section{REFERENCES}

Kaplan R.S dan David P. Norton. (2000). Balance Scored. Menerapkan Strategi Menjadi Aksi. Erlangga. Jakarta.

Masdupi, (2005). Analisis Dampak Struktur Kepemilikan pada Kebijakan Hutang dalam Mengontrol Konflik Keagenan. Jurnal Ekonomi Bisnis, 20(1), 56-59

Moeljadi. (2006). Manajemen Keuangan: Pendekatan Kuantitatif dan Kualitatif. Jilid 1. Malang. Bayu Media Publishing.

Munawir. (2011). Analisis Laporan Keuangan. Liberty. Edisi kelima. Yogyakarta.

Nurul Aisyiah, (2013). Pengukuran Kinerja Keuangan Perusahaan Menggunakan Metode Rasio Keuangan dan Metode Eva (studi kasus PT. Kalbe Farma). Jurnal Administrasi Bisnis $(J A B), 2(1)$ quality of service to the community. If social benefits are prioritized, then the target of increasing the pipeline network and improving clean water services to the community can be a priority, so that the addition of equity participation in the Tirta Mukti Public Corporation can also be prioritized.

Peraturan Pemerintah No. 27 Tahun 2014 tentang Pengelolaan Barang Milik Negara $(\mathrm{BMN}) /$ Barang Milik Daerah (BMD)

Peraturan Menteri Dalam Negeri Nomor 52 Tahun 2012 tentang Pedoman Pengelolaan Investasi Pemerintah Daerah

Sjamsuridjal dan Abin Suarsa. (2017). Kajian Kemampuan Keuangan Daerah untuk Pertimbangan Penempatan Modal Daerah pada BUMD Studi Kasus APBD Pemerintah Kabupaten Cianjur 2017. Jurnal Riset Akuntansi Mercu Buana (JRAMB), 3(1)

Srimindarti. (2006). Balanced Scorecard Sebagai Alternatif untuk Mengukur Kinerja. STIE Stikubank. Semarang.

Sutrisno. (2009). Manajemen Keuangan Teori, Konsep dan Aplikasi. Ekonisia. Yogyakarta

Undang-undang 23 Tahun 2014 tentang Pemerintahan Daerah 